\title{
The Correlation of Peer Conformity and Parents Support with Juvenile Delinquency
}

\author{
AghniaSadida ${ }^{1}$, Herman Nirwana ${ }^{2}$, Riska Ahmad ${ }^{3}$ \\ ${ }^{123}$ Universitas Negeri Padang, Padang - Indonesia, (aghnia_sadida@yahoo.co.id)
}

\begin{abstract}
The purposes of this study are to test correlation peer conformity, parents support, juvenile delinquency, and the peer conformity, parental support, partially and simultaneously with the juvenile delinquency. The sample consisted of 115 people taken by using the stratified random sampling. The results show that there is correlation of peer conformity to juvenile delinquency was $-0,235$, the correlation of parents support to juvenile delinquency was $-0,206$ and the correlation of peer conformity and parents support to juvenile delinquency was $-0,292$.
\end{abstract}

Keywords: peer conformity, parents support,juvenile delinquency.

This is an open access article distributed under the Creative Commons 4.0 Attribution License, which permits unrestricted use, distribution, and reproduction in any medium, provided the original work is properly cited. $\odot 2018$ by author and Faculty of education, UniversitasNegeri Padang.

\section{Introduction}

Adolescence is a period of transition from children to adults who have an age range of 11-21 years old. The role of progress focused on efforts to change attitudes and childish behavior and striving to achieve the ability to behave and behave in an adult manner. Thus, if these developmental tasks cannot be met then there will be gaps and mismatches of reality that should occur in adolescents

Considering so many roles of progress which teenagers must reach, surely will be many problems that are teenagers among others, such as the behavior of teenage acquaintances. stock 2002:22 state that juvenile delinquency term refers to something broad behavioral range, ranging from behavior that is not socially acceptable (such as acting excessively in the school), offense (like run away from home), until the crime (such as steal).

Juvenile delinquency is influenced by emotional, psychic, and physical development, so teenagers find it difficult to find their identity and cannot tell what is good and what is bad. Failure experienced by adolescents can be caused by unresolved conflicts in childhood or in adolescence. Juvenile delinquency is often done by teenagers whose economic needs are not met even not only delinquency but his actions include criminal or criminal crimes.

The results of the research by Anggellia (2012) indicate that $79.23 \%$ of the students are in medium or moderate score category in perceiving Juvenile Delinquency, meaning 164 students who only know about Juvenile Delinquency but in the assessment and reflection on their 
behavior tend to make mistakes. Furthermore, based on data from Pramong Praja Police Unit (Satpol PP) in West Sumatra, especially Padang City during the year 2016 recorded 433 cases of juvenile delinquency.

The result of Rinaldi's research (2017) suggests that the behavior of juvenile delinquency as a whole is in a high category as much as $41.18 \%$, medium category $33.82 \%$ and low category $19.82 \%$. It is understandable that the problems of conformity, self-concept, and juvenile delinquency still occur especially among learners so it needs to be taken seriously. Juvenile delinquency undertaken by young people under a certain age is one form of juvenile delinquency referred to as status offenses (offenses status). The form of juvenile delinquency such as run from home, skipping school, drinking alcohol that violates the provisions of age, prostitution, and the inability to control themselves.

Many factors that influence juvenile delinquency include: (1) identity, (2) self-concept, (3) age, (4) gender, (5) expectation of education, (6) parental support, (7) peer conformity , (8) socioeconomic status, and (9) environmental quality (Santrock, 2012). Based on the explanation, one of the factors that cause juvenile delinquency is peer conformity. At this time, peer group influences were enormous while parental and community controls were reduced. Teenagers often reject everything that is considered good by parents. Gunarsa (2008) states that one of the most common symptoms is the onset of delinquency in adolescence caused by a shift in the relationship between parent and adolescent children.

Relationships with peers play an important role in juvenile delinquency. Chaplin (2009) states that conformity is a tendency to be influenced by group pressure and not to oppose norms that have been applied or outlined by groups. The existence of norms in groups of peers causes teenagers difficult to believe themselves and tend to be more confident in peer groups. Teenagers spend more time with peers than in childhood. This is supported by the opinion of Papalia, Olds \& Feldman (2009) the strongest peer influence in early adolescence, usually peaking at age 12-13 years and decreasing during middle and late adolescence, along with improved adolescent relationships with parents.

Conformity to peers in adolescence can be positive or negative. Adolescents engage in any kind of negative conformity behavior, for example, they use slang, steal, damage, and play with parents and teachers. However, a large number of peer conformities, among others, dress like friends and want to spend a lot of time with one click or gang members and reflect the desire to engage in a world of peers. Peers can introduce teenagers to alcohol, drugs, delinquency, and other forms of behavior adults see as maladaptive.

The results of the Santor, Messervey, \& Kusumakar (2000: 178) studies show that "Peer conformity has a strong influence on risk behaviors such as drug use, misbehavior, and low learning achievement". Furthermore, the results of Putri's (2017) study show that peer conformity affects the behavior of students, if there is one student who is not disciplined, truant or others then there are often other students who follow-up so that discipline violations by students increasing. It is not all teenagers will imitate and be directly influenced by all activities done by peer conformity in order to be accepted and acknowledged to exist in the group. There 
are also teenagers who tend to be more considerate of everything before doing acts that can harm themselves and that are not in accordance with existing social norms without any coercion from peers.

In addition to peer conformity, other factors that also affect juvenile delinquency are parental support (Santrock, 2003). The greatest support in the home environment is sourced from parents. Parental support, which reflects parents' responsiveness to a child's needs, is very important for the child. Ellis, Thomas \& Rollins (in Lestari, 2012) defines parental support as an interaction developed by parents characterized by care, warmth, approval and positive feelings of parenthood toward children. Parents should give positive support and respect for children and nurture and not give false stimuli to their children. Parental support makes the child feel comfortable about the presence of the parent and confirms in the child's mind that he is accepted and acknowledged as an individual.

The result of Triyono's research (2015) shows that most of the students get very high support from parent for education that is equal to $48,9 \%$, some other students get high support that is equal to $39,7 \%$, and some other students get medium support by $11.4 \%$. Then research conducted by Sarman (2015) explained that $81.5 \%$ on average the level of support parents are in the high category. From the research result, it is found that the support of parents to the students is in the high category, while the phenomenon that occurs in the field indicates the support of parents is still low.

Poole \& Regoli (1979: 188) states that "Lack of family support is viewed as conducive to delinquency. This weak or broken bond ostensibly minimizes one's sensitivity to the opinions or expectations (i.e., norms) of others, freeing the individual to deviate. Conversely, the presence of control via parental support is seen as inhibiting delinquency".

In order to reduce the level of juvenile delinquency that often occurs in schools then the need for BK services. BK services are an integral part of education by facilitating students, in order to achieve full and optimal student development with an independent personal focus and selfcontrol (Prayitno, 2013). In schools, BK services are provided through various means and activities such as information sharing, improve teaching, group guidance and more. BK service activities in schools are to carry out coaching in areas related to personal, social, learning and career development (Permendikbud No. 111, 2014).

Counselor Teachers / Counselors in dealing with student problems cooperate with various other parties such as teachers, parent, guardian, school order officer, student waka, and others. Due to the problem of students is not solely the responsibility of the Teacher BK / Counselor only, but the responsibility of all components in the school to help the smooth service of BK in order to overcome the problem of students including juvenile delinquency problems in school.

Juvenile delinquency is part of the personal and social development field which is one of the focus of BK services. By knowing the picture of juvenile delinquency, as well as related factors such as peer conformity and parental support, can be used as needs analysis. The data can be a reference in preparing BK service program in school, so that service in school more optimal and right target. The purpose of the study was to test: (1) peer conformity, (2) parents support, (3) 
juvenile delinquency, and (4) peer conformity correlation, parents support partially and simultaneously with juvenile delinquency.

\section{Method}

The type of this research is the descriptive correlation. The population of the research is all students of SMA Baiturrahmah Padang that includes classes X, XI and XII registered in the academic year 2017/2018 which amounted to 162 people and the sample in this study were 115 people. Sampling technique using stratified random sampling technique. Instruments such as Likert scale, peer conformity scale, parents support, and juvenile delinquency. The results of reliability test using alpha Cronbach formula peer conformity scale of 0.935 , parents support the scale of 0.951 and juvenile delinquency of 0.973 . Besides, it is also used a technique of halving by dividing two items based on peer conformity scale with value 0,942 , parents support scale with value 0,963 , and juvenile delinquency with value 0,973 .

\section{Results and Discussion}

1. Peer Conformity Relationships with Juvenile Delinquency

The results of this study indicate that peer conformity is negatively associated with significant juvenile delinquency. These findings were obtained based on a series of data analyzes showing that the peer conformity significance test with juvenile delinquency. That is, peer conformity is one factor that is considered to cause adolescent misbehavior. This is shown by the obtained Fcount value of 6.596 with Sig. $0.012 \leq 0.05$.

The study findings show that on average the overall peer conformity is in a low category. As for the intended low is that the tendency of students to imitate the behavior of his friend does not require consideration in accordance with the thoughts, feelings, experiences, and spirit. $t$ is possible that students will imitate the behavior of the idolized, popular and who must be trusted, followed, and imitated in their school environment. This is what makes students more likely to imitate and follow what the will of others without understanding, consideration through thoughts, feelings, experiences, and passion that arises in him. Such circumstances can be understood that students have blind peer conformity. This is one that can cause negative effects for students, for example, students easily fall into juvenile delinquency, where students immediately follow what actions appear on peer groups, whether negative or positive. If students have positive peer conformity, they will avoid delinquent teenage misbehavior in the school environment, because the decision is entirely in the hands of students who want to sit in a certain position whether to imitate or not imitate (Prayitno, 2009).

Conformity is a form of behavior that is influenced by peers / social groups so that adolescents can be appreciated, accepted, and participated in the social group. Santrock (2003) states that conformity arises when individuals mimic the attitudes/behavior of others due to 
the real or imagined pressure on them. This is supported by research conducted by Mulyasri (2010) explains that there is a positive relationship between peer conformity with juvenile delinquency, adolescents who conform and focus on negative activities will trigger the emergence of juvenile delinquency. Furthermore, the results of Santor's research, Messervey, \& Kusumakar (2000: 178) show that peer conformity has a strong influence on risky behaviors such as drug use, misbehavior, and low learning achievement. But this is not all students want to imitate and directly affected by all activities undertaken by peers to be accepted and recognized existence. There are also students who tend to internally consider everything before committing an act that can be self-defeating and that is inconsistent with existing social norms without coercion from peers. In this study the negative relationship of peer conformity with juvenile delinquency, which means that the higher the peer conformity that occurs it will lower the juvenile delinquency and vice versa if the conformity of high peers automatically juvenile delinquency will be lower.

Based on the above explanation, Counselor Teachers have a role to follow up the results of this research, by making BK program implemented through the implementation of BK service. This is done to prevent negative conformity and to develop positive conformity among students by means of which students can select the association with whom should be friends with peers. This research data can be used as Teacher BK / Counselor as a process of student needs analysis. Needs analysis is then used as a Counselor Teacher / Counselor as a material of BK program to provide services so that students are able to develop their potential in a more positive direction.

\section{Parents Support Relationships with Juvenile Delinquency}

The results of this study indicate that parents support is negatively associated with significant juvenile delinquency. These findings were obtained based on a series of data analyzes showing that the significance test of parents supports juvenile delinquency. That is, parents support is one factor that is considered to cause teenagers to make mischief. This is shown by the calculated F-value of 5.013 with Sig. $0.027 \leq 0.05$.

The study findings show that on average the overall support of parents is in a low category. The low support of parents experienced by students can be interpreted that support and encouragement to students morally and materially from parents are still very less. It is known that all indicators are in a low category. These low parents support conditions need to be further improved to help students discover a clearer identity, improve self-esteem and improve problem-solving skills.

The greatest support in the home environment is sourced from parents. Sarafino \& Smith (2011) states "Support can come from many sources the person's spouse or lover, family, friends, physician, or community organizations". Then King (2012) explains that parental support shows that a person is loved, cared for, valued, respected, engaged in communication 
networks and mutual obligations. This means that parental support to students will make feel that their existence is really expected. Parents who provide good direction and guidance will form good teenagers and if otherwise, parents who tend to let teenagers, then the teenager will be difficult to develop himself. Poole \& Regoli (1979: 188) states that "Lack of family support is viewed as conducive to delinquency. This weak or broken bond ostensibly minimizes one's sensitivity to the opinions or expectations (i.e., norms) of others, freeing the individual to deviate. Conversely, the presence of control via parental support is seen as inhibiting delinquency".

In this study, there is a negative relationship of parents support with juvenile delinquency, which means the higher the support of parents that occur then the lower the juvenile delinquency and vice versa if the low parents support automatic juvenile delinquency will be higher. Based on the above explanation, Counselor Teacher / Counselor plays an important role to improve and develop the support of parents who are still low. Through optimal and professional BK service, Counselor Teachers provide information to parents to give good parents support to the students so that it directly affects the reduction of juvenile delinquency. In addition, parents should be able to work together with the school to jointly guide and control students. Parents should be able to provide the appropriate support and the students need to reduce the level of delinquency of teenagers that often occur. Good cooperation between parents and teachers BK / Counselor, facilitate the work of teachers BK / Counselor in carrying out guidance to the right students.

\section{Peer Conformity Relationships and Parents Support Together with Juvenile Delinquency}

The results explain that peer conformity and parents support are jointly associated with juvenile delinquency. It can be interpreted, that the variables of peer conformity and parents support together contributes to juvenile delinquency. That is, negative peer conformity and poor parents support together can have an impact on juvenile delinquency that goes against the norms that exist both in the school environment and in the community. This is indicated by the obtained Fhitung value of 5.230 with Sig. $0.007 \leq 0.05$. Although in the results of this study there is little difference in donations, in which parents support variables slightly outweigh the contribution compared to peer conformity.

The large contribution of parents support compared to peer conformity is a natural thing, because the best social support is the support gained from the parent family. Parents as part of the family are the individuals closest to the student and one source of support for students in the family. Parents support is the most important support system in adolescence. Students need encouragement to see what's going on around them, and need help to understand what's going on around them, students need people to love them, get affection and show a safe target for anger and aggression, students also need help to be accepted, appreciated, needed as a family member, including parents (Goldstein, et al in Maharani \& Andayani, 2003). 
Parents support can provide ease in the development of students, both in the form of moral and material support. Positive parents support relates to the close relationship between parent and child, high self-esteem and advanced moral development (Gunarsa, 2008). Students who get attention and support from parents tend to be able to place themselves in their social environment. One of the social environment of students is with peers. Peers have an important role in the social life of students. Students feel so warm and comfortable to be in peer conformity. However, peer conformity can also encourage students to anti-social tendencies. This can be interpreted that the more positive the peer conformity, the better the behavior will be raised. And vice versa, the more negative the peer conformity, the less good is also the behavior raised.

The factors that influence juvenile delinquency according to Santrock (2012) are as follows: 1) identity, 2) self-concept, 3) age, 4) gender, 5) expectations of education, 6) parents support, 7) peer conformity, 8) socioeconomic status, and 9) environmental quality. The results of this study also would emphasize, that there are several factors that can give effect to juvenile delinquency namely peer conformity and parents support.

Furthermore, the results of the study explain that there is a joint relationship between peer conformity and parents support with juvenile delinquency, from the results need to manage good cooperation between parents, teachers, and society to reduce and prevent occurrence of juvenile delinquency that often happens adolescents can develop and enhance deeds in accordance with the values and norms that exist in the school environment, family, and society.

Based on the previous explanation, it can be concluded that peer conformity and parents support can give effect to juvenile delinquency. That is, if the higher the negative peer conformity and poor parents support, then the higher the happening of juvenile delinquency. The results of these studies need to be followed up to prevent delinquent teenage misbehavior occurring in the school environment and in the community. Counselor Teachers have a role to follow up the results of this research, by making BK program and optimizing BK service in accordance with the needs of students through information services, group guidance services and consulting services by discussing topics related to peer conformity that is about building a good relationship between peers and know themselves through Petak Johari Window, then topics related to parents support is one of them on how to establish effective communication with parents and the topic related to juvenile delinquency is about distancing themselves from things that trigger juvenile delinquency, negative impact of the dangers of smoking and efforts changing student skipping behavior. 


\section{Conclusions}

There is a significant negative relationship between peer conformity with juvenile delinquency. This means that the higher the peer conformity, the lower the juvenile delinquency.

There is a significant negative relationship between parents support and juvenile delinquency. This means, that the higher the support of parents the lower the juvenile delinquency.

There is a significant relationship between peer conformity and parents support simultaneously with juvenile delinquency. This means, that the high level of juvenile delinquency is not only related to one variable alone but relates in tandem with peer conformity and parents support.

Thus, to reduce the high juvenile delinquency that occurs, the Counselor Teachers can arrange and make the program with actual materials and carry out supporting activities as the basis for the preparation of the program is that the expected BK services is really in accordance with the students' needs such as providing information on how to improve positive peer conflicts and the negative impact of lack of parents support provided to students' by using other types of services.

\section{References}

Anggellia, A. Y. (2012). "Hubungan Konsep Diri dengan Persepsi Siswa tentang Juvenile Delinquency (Kenakalan Remaja) dan Implikasinya dalam Bimbingan dan Konseling (Studi di SMA Negeri 1 Seberida Kabupaten Indragiri Hulu)". Tesis tidak diterbitkan. Padang: PPs UNP.

Chaplin, J. P. (2009). Kamus Lengkap Psikologi. Jakarta: Rajawali Press.

Gunarsa, S. D. (2008). Psikologi Perkembangan Anak dan Remaja. Jakarta: Gunung Mulia.

King, Z. (2012). Career Self-Management: Its nature, causes and consequences. Journal of Vocational Behavior, 1 (25).

Lestari, S. (2012). Psikologi Keluarga: Penanaman nilai dan penanganan konflik dalam keluarga. Jakarta: Kencana.

Maharani, O. P., \& Andayani, B. (2003). “Hubungan antara Dukungan Sosial Ayah dengan Penyesuaian Sosial pada Remaja Laki-laki”. Jurnal Psikologi, (1): 23-25.

Mulyasri, D. (2010). “Kenakalan Remaja Ditinjau dari Persepsi Remaja terhadap Keharmonisan Keluarga dan Konformitas Teman Sebaya". Tesis tidak diterbitkan. Surakarta: Program Pascasarjana Universitas Sebelas Maret. 
Papalia, Olds., \& Feldman. (2009). Human Development: Perkembangan manusia. Terjemahan oleh A. K. Anwar. Jakarta: Salemba Humanika.

Permendikbud Nomor 111 Tahun 2014 tentang Bimbingan dan Konseling pada Pendidikan Dasar dan Pendidikan Menengah. Jakarta: Kementerian Pendidikan dan Kebudayaan Republik Indonesia.

Poole, E. D., \& Regoli, R. M. (1979). “Parental Support, Delinquent Friends, and Delinquency: A test of interaction effects, 70 (2): 188-193.

Prayitno. (2013). Konseling Integritas. Padang: UNP Press.

Prayitno. (2009). Dasar Teori dan Praksis Pendidikan. Jakarta: Gramedia Widiasarana Indonesia.

Putri, M. A. (2017). “Kontribusi Kepercayaan Diri dan Konformitas Teman Sebaya terhadap Kedisiplinan Siswa di MTs Al Furqon Padang serta Implikasinya dalam Pelayanan Bimbingan dan Konseling". Tesis tidak diterbitkan. Padang: Program Studi S2 BK FIP UNP.

Rinaldi. Y. (2017). “Hubungan Konformitas Teman Sebaya dan Konsep Diri dengan Perilaku Kenakalan Remaja serta Implikasinya dalam Bimbingan dan Konseling". Tesis tidak diterbitkan. Padang: Program Studi S2 BK FIP UNP.

Santor, D. A., Messervey, D., \& Kusumakar, V. (2000). “Measuring Peer Pressure, Popularity, and Conformity in Adolescent Boys and Girls: Predicting school performance, sexual attitudes and substance abuse". Journal of Youth and Adolescence, 29 (2): 163-182.

Sarman, F. (2015). “Hubungan Dukungan Orangtua dan Locus of Control dengan Pemantapan Arah Pilihan Karier Siswa serta Implikasinya dalam Pelayanan Bimbingan dan Konseling. Tesis tidak diterbitkan. Padang: Program Studi S2 BK FIP UNP.

Sarafino, E. P., \& Smith, T.W. (2011). Health Psychology: Biopsychosocial interaction. New York: John Willey dan Sans Inc.

Santrock, J. W. (2002). Perkembangan Masa Hidup. Terjemahan oleh Juda Damanik \& Achmad Chusairi. Jakarta: Erlangga.

Santrock, J. W. (2003). Adolescence: Perkembangan remaja. Terjemahan oleh Shinto B. Adelar \& Sherly Saragih. Jakarta: Erlangga.

Santrock, J. W. (2012). Life-Span Development: Perkembangan masa hidup. Terjemahan oleh Juda Damanik \& Achmad Chusairi. Jakarta: Erlangga.

Satuan Polisi Pamong Praja (Satpol PP). 2016. Pelaku Kenakalan Remaja. (Online) tersedia di http://www.polpp.padang.blogspot.co.id. (diakses 26 Februari 2017). 
Triyono. (2015). “Kontribusi Dukungan Orangtua dan Persepsi Siswa terhadap Tingkat Aspirasi Pendidikan Lanjutan serta Implikasinya dalam Bimbingan dan Konseling". Tesis tidak diterbitkan. Padang: Program Studi S2 BK FIP UNP. 